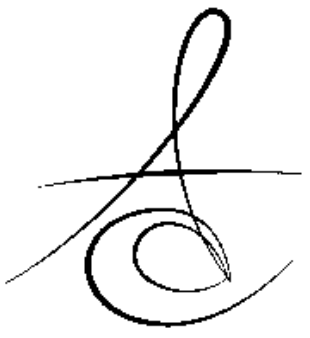

\section{SERBEST ÇALIŞAN DİŞ HEKİMLERİNİN TOTAL PROTEZ YAPIMI SIRASINDA KULLANDIKLARI TEKNİKLERİN VE MATERYALLERİN ARAŞTIRILMASI}

\author{
STEPS, TECHNIQUES AND MATERIALS USED MAKING COMPLETE DENTURES \\ - A SURVEY
}

Doç. Dr. Ş. Begüm TÜRKER**

Makale Kodu/Article code: 2711

Makale Gönderilme tarihi: 24.03.2016

Kabul Tarihi: 11.05..2016

\section{ÖZET}

Amaç. Çalışmamızın amacı, serbest çalışan diş hekimlerinin total protez yapımı sırasında izlediği aşamaları, kullandıkları teknikleri ve materyalleri incelemektir.

Gereç ve Yöntem. Çalışmada total protez aşamalarını içeren 18 soruluk bir anket kullanıldı. Anket çalışması 1974 ve 2013 yılları arasında mezun olmuş, rastgele seçilen yaşları 24 ila 57 arasında olan 50 diş hekimiyle (28 kadın, 21 erkek) yapıldı. Sonuçların analizi tanımsal istatistiklerden yüzdelik frekanslarla yapıldı.

Bulgular. Çalışmaya katılan diş hekimlerinin \%50'sinin ikinci ölçü alımında çinko oksit öjenol kullandığı, \%90'ının dikey boyut belirlemede Niswonger yöntemi kullandığı, \%94'ünün yüz arkı kullanmadığı, \%46'sının yüz arkı kullanarak ve kullanmadan yapılan protezler arası fark olmadığını düşündüğü, \%86'sının mandibulada stabilizasyonu çoğunlukla sağladığını, \%54'ünün maksillada stabilizasyonu her zaman sağladığı, \%56'sının protez sonrası besleme ihtiyacı duyduğu, \%78'inin protez yapıştırma ajanlarını önermediği ve \%86'sının total protez yapmayı sevdiği bulunmuştur.

Sonuçlar. Çalışmamızda elde edilen veriler sonucunda, total protez yapımında serbest çalışan diş hekimlerinin kullandıkları yöntem ve materyallerin, fakültede verilen total protez eğitimi sırasında kullandıkları yöntem ve materyallere yakın olduğu rapor edilmiştir. Bununla beraber, bu konuda ileri araştırmalar yapılması gereklidir.

Anahtar Kelimeler: Tam protez, Teknik, Materyal

\section{ABSTRACT}

Aim: The aim of this study was to identify the steps, techniques and materials used in making complete dentures in general dental practice.

Materials and Methods. A questionnaire with 18 questions, including the step by step phases of complete denture making were used in this study. Questionnaires were filled by randomly chosen 50 dentists who work out of the faculties and graduated between 1974 and 2013 years. Results were determined by percentiles.

Results. Survey was showed that $50 \%$ of the dentists were using zinc oxide eugenol as secondary impression material. $90 \%$ of the dentists were using Niswonger method to assess the vertical dimension. $94 \%$ of the dentists were not using face bow, and $46 \%$ of the dentists thought that there was any difference between the denture made by using face bow or not. $86 \%$ of the dentists were reported they could mostly provide the stabilization of the mandibular denture. $54 \%$ of the dentists were reported they could always provide the stabilization of the maxillary denture. $56 \%$ of the dentists were needed relining after completing denture. $78 \%$ of the dentists were not recommending use of a denture adhesive. And $86 \%$ of the dentists were liked making complete dentures. Conclusions. Survey results were showed that, the steps, techniques and materials used in making complete denture in general dental practice were nearly the same with the steps, techniques and materials used in complete denture education. Although, further investigation was needed.

Keywords: Complete denture, Technique, Material

\footnotetext{
*', Zonguldak Bülent Ecevit Üniversitesi Diş Hekimliği Fakültesi, Ağız, Diş ve Çene Cerrahisi AD

*** Marmara Üniversitesi Diş Hekimliği Fakültesi, Protetik Diş Tedavisi $A D$
}

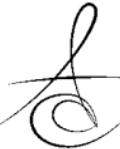




\section{GİRIŞ̧}

Tam protez yapımı çok etaplı bir tedavidir. Tedavi prosedürleri, klinik ve radyografik muayene ile başlar, teşhis ölçüsü veya birinci ölçü alımı ile devam eder. Total protezlerde ölçü alınırken hazır kaşık kullanılması sonucu, dil, yanak, dudak veya ağız tabanı normal konumundan uzaklaşır ve doğru bir ölçü alınmaz. Metal kaşıklar dişsiz alveol kretlerinde kulanılabilir ancak her vakaya her durumda uyumlu değillerdir. Bu nedenle, hastanın ağız dokularının konturları ile tam uyumlu düzgün bir son ölçü metal kaşıklarla alınamaz. Hastaya ait özel bir kaşık yapılması gereklidir. ${ }^{4}$ Kenar şekillendirme parça parça veya tek parça halinde yapılır ve ikinci ölçü alınır, kaide plaklarının yapımı, mum duvarların hazırlanması, dikey boyutun tespit edilmesi, horizontal çene ilişkilerinin kaydının alınması ve artikülatöre modellerin transferinden sonra, diş seçimi diş dizimi, dişli prova, modelaj ve protezlerin laboratuvarda bitirilmesi, oklüzal ilişkilerin tekrar kontrol edilmesi için tekrar artikülatöre alınması ve gerekli aşındırma işlemlerinin yapılması sonucunda protezler hastaya teslim edilir. Tam protezlerin yapımı sırasında birçok teknik ve birçok materyal kullanılmaktadır. ${ }^{1-4}$

Tam protezin yapım aşamalarını anlatan, değişik klinik vakalarda uygulanan teknikleri ve kullanılan materyallerle ilgili detaylı bilgi veren birçok kitap bulunmaktadır. Diş Hekimliği Fakültelerinde tam protez yapımı ilgili kitaplar ve literatürler ışığı altında anlatılmakta ve öğretilmektedir. Literatürde serbest çalışan diş hekimlerinin diş hekimliği eğitiminde öğretilen tekniklerin pratikte uyguladıkları tekniklerin uyuşmadığı rapor edilmiştir. ${ }^{5-8} \mathrm{Bu}$ çalışmanın amacı, serbest çalışan diş hekimlerinin total protez yapımı sırasında izlediği aşamalar, kullandıkları teknikler ve materyalleri incelemektir.

\section{GEREÇ ve YÖNTEM}

Serbest çalışan diş hekimlerinin total protez yapımında izledikleri aşamalar, bu aşamalarda dikkat ettikleri noktalar, kullandıkları teknikleri ve materyalleri incelemek amacıyla Marmara Üniversitesi Diş Hekimliği Fakültesi Protetik Diş Tedavisi Anabilim Dalı'nda 18 soruluk bir anket hazırlandı. Çalışma grubu 50 kişiden oluşturuldu ve çalışmaya 24 ve 57 yaşlar arası 28 kadın 21 erkek diş hekimi katıldı. Ankete katılan 50 kişi arasında, 4 protetik diş tedavisi uzmanı, 1 restoratif diş tedavisi uzmanı, 1 pedodonti uzmanı ve 44 pratisyen diş hekimi bulunmaktadır.
Anket toplam 18 sorudan oluşmaktadır (Tablo 1). İlk bölümde, ankete katılan diş hekimlerine mezuniyet yılı, yaşı, cinsiyeti, var ise uzmanlık alanı, kaç senedir diş hekimliği yaptığı ve ortalama tedavi ettikleri total protez hasta sayısı sorulmuştur. Anketin ikinci bölümü, total protezin yapım aşamalarını içeren sorulardan oluşmuştur ve ankete katılan diş hekimlerinin preprotetik inceleme yapıp yapmadıkları ve protezin yapımı aşamasında dikkat edilmesi gereken faktörlerle ilgili 9 soru sorulmuştur. Anketin üçüncü bölümünde ise tam protez hastaya uygulandıktan sonra dikkat edilmesi gereken faktörleri içeren 6 soru daha sorulmuştur. Çalışmada elde edilen bulgular değerlendirilirken, istatistiksel analizler için SPSS Windows 17.0 programı kullanılmıştır. Çalışma verileri tanımlayıcı istatistiksel metotlardan yüzdelik frekanslarla hesaplanmıştır.

Tablo 1: Anket Örneği

Serbest Çalışan Diş Hekimleri Arasında Tot

Protez Yapım Aşamaları, Teknikleri ve Kullanılan

Materyaller Hakkında Araştırma Anketi -

Ad: Soyad:

Yaş: Cinsiyet:

Fakülte/Mezuniyet yill:

Uzmanlık Alanı: Var / Yok

Varsa;

Ağız, Diş ve Çene Cerrahis

$\checkmark$ Endodonti

Oral Diagnoz ve Radyoloji

Ortodonti

Pedodonti

Periodontoloji

Protetik Diş Tedavisi

Restoratif Diş Tedavisi

1-Kaç senedir diş hekimliği yapıyorsunuz?

5 seneden az $\square 5-10$ sene $\square 10$ seneden fazla

2-Tedavi ettiğiniz total protez hasta sayısı

10 hastadan az $\square 10-20$ hasta $\square 20$ hastadan fazla

3-Total protez tedavisi öncesi ayrıntılı preprotetik inceleme

yapıyor musunuz? Evet / Hayı

Evet ise;

YYalnızca kret boyu, genişliği, şekil incelenmesi

IIntermaksiller kret ilişkileri incelenmesi

uLabil kretler

-Kemik, yumuşak doku undercut'lar

Fibröz doku hiperplazileri, ekzostozlar ve toruslar

口Yüksek frenulum bağlantıları

Malign/benign yumuşak doku lezyonlar

3A-Hastalarınızdan panoramik radyograf alıyor musunuz? Evet / Hayı

3B-Hastalarınıza implant tedavisi öneriyor musunuz? Evet / Hayır

3C-Overdenture öneriyor musunuz? Evet / Hayır

3D-Preprotetik incelemelerde gerektiği zaman cerrahi konsültasyonu

alıyor musunuz? Evet / Hayır

3E-Preprotetik işlemleri;

Gendim yapiyorum.

-Cerrahi uzmanına yaptıriyorum.

Herhangi bir preprotetik işlem yapmıyorum

4-Tedaviye başlamadan önce teşhis ölçüsü alıyor musunuz?

Her zaman

Gerektiği durumlarda

Almıyorum

Teşhis modeli alıyorsanız;

Kullandığınız ölçü materyali;

IIrreversibl hidrokolloid(Aljinat)

Termoplastik ölçü materyali(Kerr plak)

Ölçü alçısı

Silikun ölçı̈ materyali

5-Bireysel kaşık hazırlıyor musunuz? Evet / Hayır

Evet ise; bireysel kaşı̆̆ıkendim hazırlıyorum / $\square$ diş teknisyeni hazırlıyor. Kullandığınız materyal;

$\square$ Akrilik rezin

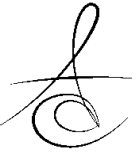




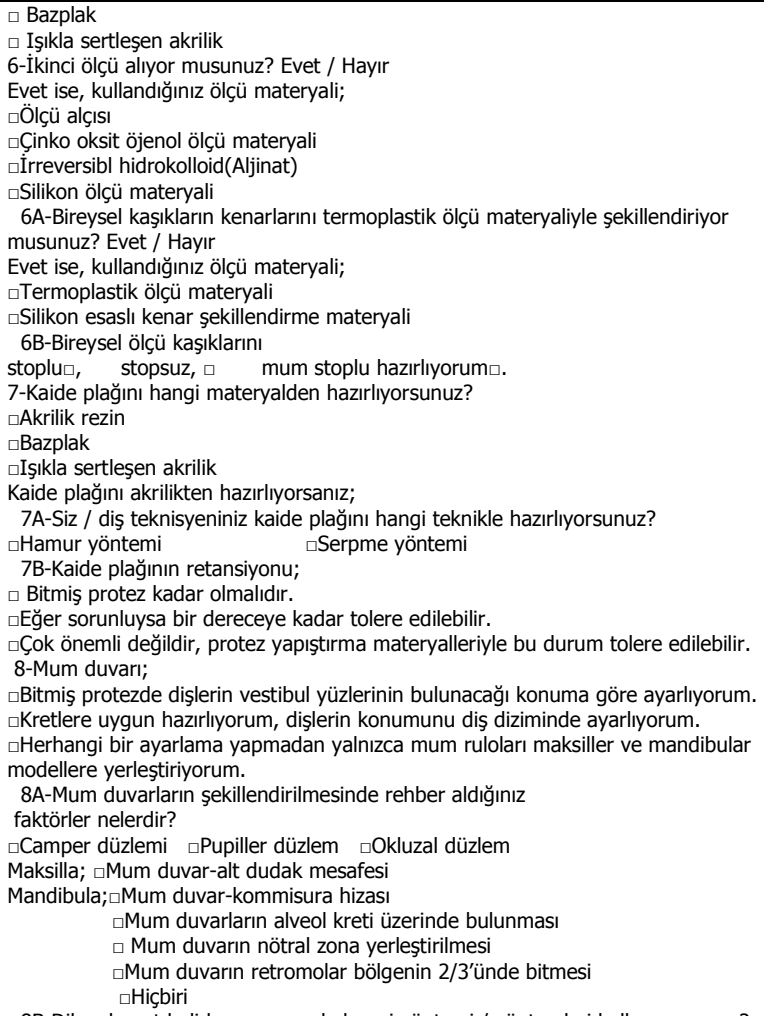

口Yüz şekli

$\square$ Hastanın isteğ

口Hiçbiri, hastaya sormadan kendim seçerim

口Hiçbiri, diş teknisyeni seçer.

11A-Diş seçiminde yapay dişin rengini seçerken dikkat ettiğiniz kriterler;

口Hastanın yaşı

-Hiçbiri, hastaya sormadan kendim seçerim.

$\square$ Hiçbiri, hastaya sormadan kend
$\square$ Hiçbiri, diş teknisyeni seçer.

11B-Total protezlerde; $\square$ porselen / $\square$ akrilik dişler tercih ediyorum.

11C-Anterior diş diziminde nelere dikkat edersiniz?

$\square$ Simetri

口Servikal bütünlük

口Dişlerin şekilleri, rengi ve yüz şekliyle olan ilişkileri

口Dudak desteği

$\square$ Açık renkli diş seçimi

口Doğal, hafif çapraşık dişler

Porselen dişlerin akrilik dișlere tercih edilmesi

$\square$ Porselen dişlerin akrilik dişlere tercih edilmesi
$\square$ Hasta tebessüm halindeyken anterior dişlerin insizal bölümlerinin alt dudak

trajesiyle uyumlu olması

口Dişlerin insizal yüzeylerinin tek düzlemde dizilmes

$\square$ Hiçbiri, diş dizimini diş teknisyenine bırakırım.

11D-Posterior diş diziminde nelere dikkat edersiniz?

$\checkmark$ Mandibular posterior dişlerin alveol kretinin üzerine dizilmesi

$\square$ Spee eğrisi

口Wilson eğrisi

$\square$ Sağ ve sol arkın aynı düzlemde bulunması

$\square$ Sağ ve sol arkın
$\square$ Dișlerin aksları

$\square$ Dişlerin aksları
$\square$ Maksiller dişlerin mandibular dişleri bir premolar genişliği kadar örtmesi

$\square$ Maksiller dişlerin mandibular dişleri bir premola
$\square$ Hiçbiri, diş dizimini diş teknisyenine bırakırım.

11E-Dişli provada nelere dikkat edersiniz?

$\square$ Sentrik ilişki ile sentrik okluzyonun çakışmas

$\square$ Diş dizimi kuralları

口Üst ve alt çenede, sağ ve sol arkların simetrik olması

$\square$ Protruziv ve lateral balansı ayarlarken, $\square 3$ nokta balansı / $\square$ full balans

sağlanması

$\square$ Dikey boyutun tekrar kontrol edilmesi

11F-Artikülasyon kanunlarını tam olarak biliyor musunuz? Evet/Hayır

11G-Artikülasyon kanunlarının birbirleriyle olan ilişkilerini yaptığııız protezlerde göz önünde bulunduruyor musunuz? Evet / Hayır

$11 \mathrm{H}$-Sizce artikülasyon kanunlarını bilmek önemli midir? Evet / Hayır

12-Klinikte bir total protezi kaç seansta tamamliyorsunuz?

व2-3 seans $\square$ 4-5 seans $\quad 6-7$ seans

13-Total protezleri ağız içinde uyumlarken Herbst testlerinden faydalanıyor musunuz? Evet / Hayır

13A-ïlk kontrolden önce, hastaya protezini kaç gün kullandırıyorsunuz?

$\square 1$ gün $\square$ 2-3 gün $\square$ 4-5 gün $\square 1$ hafta $\square 1$ haftadan fazla

13B-Yaptığım total protezlerde, mandibulada protez stabilizasyonunu;

口Tüm hastalarımda sağlayabiliyorum.

口Çoğunlukla sağlayabiliyorum.

口Nadiren sağlayabiliyorum.

口Sağlayamıyorum.

13C-Yaptığım total protezlerde, maksillada protez stabilizasyonunu

口Tüm hastalarımda sağlayabiliyorum.

口Çoğunlukla sağlayabiliyorum.

- Nadiren sağlayabiliyorum.

口Sağlayamıyorum.

14-Tedavi gören hastalarım, total protezlerinden

14-Tedavi gören hastalarım, total protezlerinden;
Memnun $\square$ Coğunlukla memnun $\square$ Kısmen memnun

$\square$ Memnun $\square$ Ço

15-Yaptığım total protezlerden;

$\checkmark$ Memnunum $\square$ Çoğunlukla memnunum $\quad$ Kıssmen memnunum

¿Memnun değilim

15A-Protezlerin başarısl;

口Hekimin tecrübesinden çok, doğrudan kullanılan materyal ve tekniklerle bağlantılıdır.

口Kullanılan materyal ve tekniklerden çok, hekimin tecrübesiyle bağlantılıdır. $\square$ Kullanilan materyal ve tekniklerden çok, hekimin tecrübesiyle bağlantılıdır.
aullanılan materyal ve tekniklerle beraber, hekim tecrübesiyle bağlantılıdır.

aKullanilan materyal ve tekniklerle beraber, hekim tecrübesiyle bağla
$15 \mathrm{~B}-T$ Total protez yaptığınız hastaları ne sıklikla kontrol ediyorsunuz?

$\square 3$ ayda bir kez $\square 6$ ayda bir kez $\square$ Yılda bir kez $\square$ Hiç kontrol etmiyorum

$15 \mathrm{C}$-Yaptığınız protezler sonradan besleme yapılmaya intiyaç duyuyor mu? Evet /

Hayır

Evet ise, beslemeye ne kadar süre sonra ihtiyaç duyuyorsunuz?

$\square$ Hastaya teslim etmeden önce

口Hastaya teslimden sonraki bir ay içinde

$\square 6$ ay-1 yıl arası

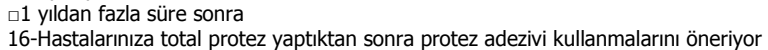
musunuz? Evet / Hayır

17-Hastalarınız total protez tesliminden sonra protez adezivi kullanma intiyacı duyuyor mu? Evet / Hayır

18-Total protez yapmayı seviyor musunuz? Evet / Hayır İLGINIZZE TEŞEKKÜR EDERIM. 


\section{BULGULAR}

Çalışmanın yüzdelik frekans verileri Tablo 2'de gösterilmektedir. Ankete katılan diş hekimlerinin \%6'sı 5 seneden az, \%10'u 5-10 sene arası. \%84'ü ise 10 seneden fazla bir süredir diş hekimliği yapmakladır. Ankete katılan diş hekimlerinin \%4'ü 10 hastadan az, $\% 8^{\prime} \mathrm{i}$ 10-20 hasta arasında, \% 88'i ise 20 hastadan fazla total protez hastası tedavi etmiş̧ir.

Tablo 2. Çalışmanın yüzdelik frekans verileri

\begin{tabular}{|c|c|c|}
\hline Soru & $\underline{\mathrm{n}}$ & \% \\
\hline \multicolumn{3}{|l|}{ 1-Kaç senedir diş hekimliği yapıyorsunuz? } \\
\hline 5 seneden az & 3 & 6 \\
\hline 5-10 sene & 5 & 10 \\
\hline 10 seneden fazla & 42 & 84 \\
\hline \multicolumn{3}{|l|}{ 2-Tedavi ettiğiniz total protez hasta sayıSI } \\
\hline 10 hastadan az & 2 & 4 \\
\hline 10-20 hasta & 4 & 8 \\
\hline 20 hastadan fazla & 44 & 88 \\
\hline \multicolumn{3}{|l|}{ 3-Preprotetik inceleme yapıyor musunuz? } \\
\hline Hayır & 1 & 2 \\
\hline Yalnızca kret boyu, genişliği, şekil incelenmesi & 37 & 74 \\
\hline İntermaksiller kret ilişskileri incelenmesi & 40 & 80 \\
\hline Labil kretler & 46 & 92 \\
\hline Kemik, yumuşak doku undercut'ları & 47 & 94 \\
\hline Fibröz doku hiperplazileri, ekzostozlar ve toruslar & 39 & 78 \\
\hline Yüksek frenulum bağlantıları & 48 & 96 \\
\hline Malign/benign yumuşak doku lezyonları & 43 & 86 \\
\hline \multicolumn{3}{|l|}{ 3A-Panoramik radyograf alıyor musunuz? } \\
\hline Evet & 48 & 96 \\
\hline Hayır & 2 & 4 \\
\hline \multicolumn{3}{|l|}{ 3B-Hastalarınıza implant tedavisi öneriyor musunuz? } \\
\hline Evet & 45 & 90 \\
\hline Hayır & 5 & 10 \\
\hline \multicolumn{3}{|l|}{ 3C-Overdenture öneriyor musunuz? } \\
\hline Evet & 36 & 72 \\
\hline Hayır & 11 & 22 \\
\hline \multicolumn{3}{|c|}{$\begin{array}{l}\text { 3D-Preprotetik incelemelerde gerektiği zaman cerrahi konsültasyonu alıyor } \\
\text { musunuz? }\end{array}$} \\
\hline Evet & 48 & 96 \\
\hline Hayır & 2 & 4 \\
\hline \multicolumn{3}{|l|}{ 3E-Preprotetik işlemleri, } \\
\hline Kendim yapıyorum & 10 & 20 \\
\hline Cerrahi uzmanına yaptırıyorum & 46 & 92 \\
\hline Herhangi bir preprotetik ișlem yapmıyorum & 0 & 0 \\
\hline \multicolumn{3}{|c|}{ 4-Tedaviye başlamadan önce teşhis ölçüsü alıyor musunuz? } \\
\hline Her zaman & 5 & 10 \\
\hline Gerektiği durumlarda & 22 & 44 \\
\hline Almiyorum & 22 & 44 \\
\hline \multicolumn{3}{|l|}{ Kullandığınız ölçü materyali; } \\
\hline İrreversibl hidrokolloid(Aljinat) & 27 & 54 \\
\hline Termoplastik ölçü materyali(Kerr plak) & 0 & 0 \\
\hline Ölçü alçısI & 0 & 0 \\
\hline Silikon ölçü materyali & 0 & 0 \\
\hline \multicolumn{3}{|l|}{ 5-Bireysel kaşık hazırlıyor musunuz? } \\
\hline Evet & 45 & 90 \\
\hline Hayır & 5 & 10 \\
\hline \multicolumn{3}{|l|}{ Bireysel kaşığl; } \\
\hline Kendim hazırlıyorum & 0 & 0 \\
\hline Diş teknisyeni hazırlıyor & 45 & 100 \\
\hline \multicolumn{3}{|l|}{ Kullandığınız materyal; } \\
\hline Akrilik rezin & 27 & 54 \\
\hline Bazplak & 24 & 48 \\
\hline Işıkla sertleşen akrilik & 19 & 38 \\
\hline \multicolumn{3}{|l|}{ 6-İkinci ölçü alıyor musunuz? } \\
\hline Evet & 48 & 96 \\
\hline Hayır & 2 & 4 \\
\hline \multicolumn{3}{|l|}{ Kullandığınız ölçü materyali; } \\
\hline Ölçü alçısı & 1 & 2 \\
\hline Çinko oksit öjenol ölçü materyali & 25 & 50 \\
\hline İrreversibl hidrokolloid & 19 & 38 \\
\hline Silikon ölcü materyali & 5 & 10 \\
\hline
\end{tabular}

\begin{tabular}{|c|c|c|}
\hline $\begin{array}{l}\text { 6A-Bireysel kaşıkların kenarlarını termoplastik ölçü materyaliyle } \\
\text { şekillendiriyor musunuz? }\end{array}$ & & \\
\hline Evet & 36 & 72 \\
\hline Hayır & 14 & 28 \\
\hline Kullandığınız ölçü materyali; & & \\
\hline Termoplastik ölçü materyali & 29 & 58 \\
\hline Silikon esası kenar şekillendirme materyali & 11 & 22 \\
\hline 6B-Bireysel ölçü kaşıklarını; & & \\
\hline Stoplu hazırliyorum & 28 & 56 \\
\hline Stopsuz hazırlıyorum & 7 & 14 \\
\hline Mum stoplu hazırlıyorum & 8 & 16 \\
\hline 7-Kaide plağını hangi materyalden hazırlıyorsunuz? & & \\
\hline Akrilik rezin & 31 & 62 \\
\hline Bazplak & 18 & 36 \\
\hline Işıkla sertleșen akrilik & 16 & 32 \\
\hline 7A-Kaide plağını hangi teknikle hazırlıyorsunuz? & & \\
\hline Hamur yöntemi & 33 & 66 \\
\hline Serpme yöntemi & 0 & 0 \\
\hline 7B-Kaide plağının retansiyonu & & \\
\hline Bitmiş protez kadar olmalıdır & 14 & 28 \\
\hline Eğer sorunluysa bir yere kadar tolere edilebilir & 33 & 66 \\
\hline Çok önemli değildir & 1 & 2 \\
\hline 8-Mum duvarı; & & \\
\hline $\begin{array}{l}\text { Bitmiş protezde dişlerin vestibül yüzlerinin bulunacağı konuma } \\
\text { göre ayarlıyorum. }\end{array}$ & 35 & 70 \\
\hline $\begin{array}{l}\text { Kretlere uygun hazırlıyorum, dişlerin konumunu diş diziminde } \\
\text { ayarliyorum. }\end{array}$ & 11 & 22 \\
\hline $\begin{array}{l}\text { Herhangi bir ayarlama yapmadan yalnızca mum ruloları maksiller } \\
\text { ve mandibular modellere yerleştiriyorum. }\end{array}$ & 4 & 8 \\
\hline 8A-Mum duvarların şekillendirmesinde rehber aldığınız faktörler ne & erdir? & \\
\hline Camper düzlemi & 18 & 36 \\
\hline Pupiller düzlem & 39 & 78 \\
\hline Okluzal düzlem & 48 & 96 \\
\hline Mum duvar-alt dudak mesafesi & 39 & 78 \\
\hline Mum duvar-kommisura hizası & 31 & 62 \\
\hline Mum duvarların alveol kreti üzerinde bulunması & 48 & 96 \\
\hline Mum duvarın nötral zona yerleştirilmesi & 41 & 82 \\
\hline Mum duvarın retromolar bölgenin $2 / 3^{\prime}$ ünde bitmesi & 24 & 48 \\
\hline Hiçbiri & 0 & 0 \\
\hline 8B-Dikey boyut belirleme amacıyla hangi yöntemleri kullanıyorsunı & & \\
\hline Niswonger yöntemi & 45 & 90 \\
\hline Silverman yöntemi & 34 & 68 \\
\hline Boos yöntemi & 0 & 0 \\
\hline Alveol kretlerinin paralelliğinden yararlanma & 17 & 34 \\
\hline Eski protezin dikey boyutunun ölçülmesi & 9 & 18 \\
\hline Yutkunma yöntemi & 36 & 72 \\
\hline Herhangi bir yöntem kullanmıyorum & 0 & 0 \\
\hline $\begin{array}{l}\text { 8C-Dikey boyut tespitinde hastaya ait hangi anatomik noktaları kor } \\
\text { diyorsunuz? }\end{array}$ & & \\
\hline Nasolabial sulkus & 25 & 50 \\
\hline Mentolabial sulkus & 24 & 48 \\
\hline Nasolabial açı & 17 & 34 \\
\hline Burun ve çene ucunun birbirine yakınlığı & 44 & 88 \\
\hline Dudaklar temas halindeyken çeneler arası mesafe & 33 & 66 \\
\hline Dudak kommisuraları & 26 & 52 \\
\hline Dudakların gerginliği & 25 & 50 \\
\hline Hiçbiri & 0 & 0 \\
\hline 8D-Camper düzlemini kontrol ediyor musunuz? & & \\
\hline Evet & 17 & 34 \\
\hline Hayır & 27 & 54 \\
\hline 9-Face bow kaydı alıyor musunuz? & & \\
\hline Evet & 3 & 6 \\
\hline Hayır & 47 & 94 \\
\hline Face bow kullanmama sebepleriniz; & & \\
\hline Klinikte face-bow apareyi bulunmaması & 19 & 38 \\
\hline $\begin{array}{l}\text { Teknisyende face-bow transferi kabul edecek artikülatör } \\
\text { bulunmaması }\end{array}$ & 30 & 60 \\
\hline Kullanım bilgisi eksikliği & 3 & 6 \\
\hline Zaman alıcı olması & 13 & 26 \\
\hline Zahmetli olması & 12 & 24 \\
\hline $\begin{array}{l}\text { Face-bow transferi kullanılmadan da yeterli protezler } \\
\text { yapılabilmesi }\end{array}$ & 14 & 28 \\
\hline Face-bow kullanımının gerekliliğine inanmıyorum & 8 & 16 \\
\hline $\begin{array}{l}\text { 9A-Sizce, face bow ile ve face bow olmadan yapılmış protezler } \\
\text { arasında klinik başarı açısından fark var mıdır? }\end{array}$ & & \\
\hline Belirgin bir fark vardır & 5 & 10 \\
\hline Okluzal uyumlamalar sonrası giderilebilecek kadar fark vardır & 21 & 42 \\
\hline Hiçbir fark yoktur & 23 & 46 \\
\hline $\begin{array}{l}\text { 9B-Çalışı̆ı̆ını teknisyen face bow transferi konusunda yeterli } \\
\text { bilgi ve ekipmana sahip mi? }\end{array}$ & & \\
\hline
\end{tabular}


Dent Fac Atatürk Uni

Cilt:26, Sayı:3, Yıl: 2016, Sayfa, 448-456

Evet
Hayır

\begin{tabular}{lll} 
Evet & 3 & 6 \\
Hayır & 33 & 66 \\
\hline 10-Sentrik ilişki tespitinde hangi yöntemleri kullanıyorsunuz? & & \\
\hline \hline Hastanın dilini damağının en gerisine koyarak mum duvarların & 48 & 96 \\
sabitlenmesi & 46 & 92 \\
Yutkunma yöntemi & 18 & 36 \\
Çene ucu rehberliği & 25 & 50 \\
Çift el ile manipülasyon tekniği & 0 & 0 \\
Gotik ark çizimi & 0 & 0 \\
Terminal menteşe ekseni kayıt yöntemi & 46 & 92 \\
\hline 11-Diş seçiminde yapay diş formunu seçerken dikkat ettiğiniz kriterler; & \\
\hline \hline Hastanın cinsiyeti & 46 & 92 \\
Hastanın yaşı & 46 & 92 \\
Yüz şekli & 40 & 80 \\
Hastanın isteği & 40 & 80 \\
Hiçbiri, hastaya sormadan kendim seçerim. & 0 & 0 \\
Hiçbiri, diş teknisyeni seçer. & 0 & 0 \\
\hline
\end{tabular}

Hçbiri, diş teknisyeni seçer.

11A-Diş seçiminde yapay dişin rengini seçerken dikkat ettiğiniz kriterler

Hastanın yaşı

Hastanin iste

Hiçbiri, hastaya sormadan kendim seçerim

$43 \quad 86$

$48 \quad 96$

$0 \quad 0$

Hiçbiri, diş teknisyeni seçer

11B-Total protezlerde;

\begin{tabular}{lll}
\hline Porselen dișler tercih ediyorum & 7 & 14
\end{tabular}

Akrilik disler tercih ediyorum

11C-Anterior diş diziminde nelere dikkat edersiniz?

Simetri

Servikal bütünlük

Dişlerin şekilleri, rengi ve yüz şekliyle olan ilişkileri

Dudak desteği

Açık renkli diş seçimi

Doğal, hafif çapraşıı dișle

Porselen dișlerin akrilik dișlere tercih edilmesi

$\begin{array}{lll}\text { Porselen dişlerin akrilik dişlere tercih edilmesi } & 9 & 18 \\ \text { Hasta tebessüm halindeyken anterior dişlerin insizal bölümlerinin } & 35 & 70 \\ \text { alt dudak trajesiyle uyumlu olması } & & \end{array}$

Dişlerin insizal yüzeylerinin tek düzlemde dizilmesi $\quad \begin{array}{lll}0 & 0\end{array}$

Hiçbiri, diş dizimini diş teknisyenine bırakırım.

11D-Posterior diş diziminde nelere dikkat edersiniz?

Mandibular post. dişlerin alveol kret üzerine dizilmesi

Spee eğrisi

Wilson eğrisi

Sağ ve sol arkın aynı düzlemde bulunması

Dişlerin aksları

$\begin{array}{lll} & 30 & 60 \\ \text { Maksiller dişlerin mandibular dişleri bir premolar genişliği kadar } & 5 & 10\end{array}$

örtmesi

Hiçbiri, diș dizimini diş teknisyenine bırakııım.

11E-Dişli provada nelere dikkat edersiniz?

Sentrik ilişki ile sentrik okluzyonun çakışması

Diş dizimi kurallar

Üst ve alt çenede, sağ ve sol arkların simetrik olması

Protruziv ve lateral balansı ayarlarken 3 nokta balans

Protruziv ve lateral balansı ayarlarken full balans

Dikey boyutun tekrar kontrol edilmesi

$46 \quad 92$

$45 \quad 90$

$28 \quad 56$

$43 \quad 86$

4488

14

4

$33+66$

$\begin{array}{ll}33 & 66 \\ 50 & 100\end{array}$

50100

2652

$\begin{array}{ll}27 & 54 \\ 30 & 60\end{array}$

$0 \quad 0$

3876

$\begin{array}{ll}46 & 92 \\ 31 & 62\end{array}$

$31 \quad 62$

$19 \quad 38$

$20 \quad 40$

11F-Artikülasyon kanunlarını tam biliyor musunuz?

\begin{tabular}{llll}
\hline \hline Evet & 43 & 86 \\
\hline
\end{tabular}

11G-Artikülasyon kanunlarını yaptığınız protezlerde göz önünde

bulunduruyor musunuz?

$\begin{array}{lcl}\text { bulunduruyor musunuz? } & 40 \quad 80\end{array}$

$\begin{array}{lll}\text { Hayır } & 40 & 80 \\ & 9 & 18\end{array}$

\begin{tabular}{lcc} 
Hayır & & 18 \\
\hline $11 \mathrm{H}-$ Artikülasyon kanunlarını bilmek önemli midir? & & \\
\hline \hline Evet & 41 & 82
\end{tabular}

Hayır

$41 \quad 82$

12-Bir total protezi kaç seansta tamamliyorsunuz?

2-3 seans

4-5 seans

0

6-7 seans

$25 \quad 50$

13-Ağız içi uyumlamalarda Herbst testlerinden faydalanıyor musunu

Evet

$25 \quad 50$

16

13A-İlk kontrolden önce protezi kaç gün kullandırıyorsunuz?

$\begin{array}{ll}16 & 32 \\ 6 & 12\end{array}$

\begin{tabular}{lll}
\hline 1 gün & 2 & 4 \\
$2-3$ gün & 29 & 58 \\
$4-5$ gün & 14 & 28 \\
1 hafta & 4 & 8 \\
1 haftadan fazla & 0 & 0 \\
\hline 13B-Mandibulada stabilizasyonu; & & \\
\hline \hline Tüm hastalarımda sağlayabiliyorum & 5 & 10 \\
Çoğunlukla sağlayabiliyorum & 43 & 86 \\
Nadiren sağlayabiliyorum & 2 & 4
\end{tabular}

Sağlayamıyorum

\begin{tabular}{|c|c|c|}
\hline \multicolumn{3}{|l|}{ 13C-Maksillada stabilizasyonu; } \\
\hline Tüm hastalarımda sağlayabiliyorum & 27 & 54 \\
\hline Çoğunlukla sağlayabiliyorum & 23 & 46 \\
\hline Nadiren sağlayabiliyorum & 0 & 0 \\
\hline Sağlayamıyorum & 0 & 0 \\
\hline \multicolumn{3}{|l|}{ 14-Hastalarım total protezlerinden; } \\
\hline Memnun & 26 & 52 \\
\hline Çoğunlukla memnun & 24 & 48 \\
\hline KIsmen memnun & 0 & 0 \\
\hline Memnun değil & 0 & 0 \\
\hline \multicolumn{3}{|l|}{ 15-Yaptığım total protezlerden; } \\
\hline Memnunum & 25 & $\overline{50}$ \\
\hline Çoğunlukla memnunum & 25 & 50 \\
\hline KIsmen memnunum & 0 & 0 \\
\hline Memnun değilim & 0 & 0 \\
\hline \multicolumn{3}{|l|}{ 15A-Protezlerin başarısI; } \\
\hline $\begin{array}{l}\text { Hekimin tecrübesinden çok, doğrudan kullanılan materyal ve } \\
\text { tekniklerle bağlantılıdır }\end{array}$ & 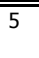 & 10 \\
\hline $\begin{array}{l}\text { Kullanılan materyal ve tekniklerden çok, hekimin tecrübesiyle } \\
\text { bağlantııdır }\end{array}$ & 4 & 8 \\
\hline $\begin{array}{l}\text { Kullanılan materyal ve tekniklerle beraber, hekim tecrübesiyle } \\
\text { bağlantılıdır }\end{array}$ & 41 & 82 \\
\hline
\end{tabular}

bağlantılidır

15B-Total protez hastalarınızı ne sıklıkla kontrol ediyorsunuz?

\begin{tabular}{lll}
\hline \hline 3 ayda bir kez & 3 & 6 \\
6 ayda bir kez & 18 & 36 \\
Yllda bir kez & 13 & 26 \\
Hiç kontrol etmiyorum & 16 & 32 \\
\cline { 1 - 2 } 15C-Yaptı̆ı̆ın protezler besleme ihtiyacı duyuyor mu? & & \\
\hline \hline
\end{tabular}

C-Yaptığınız protezler besleme intiyacı duyuyor mu?

Evet

\begin{tabular}{lll} 
Hayır & 27 & 54 \\
\hline Beslemeye ne kadar süre sonra ihtiyaç duyuyorsunuz? & & \\
\hline \hline Hastaya teslim etmeden önce & 1 & 2 \\
Hastaya teslimden sonraki bir ay içinde & 1 & 2 \\
6 ay-1 yıl arası & 13 & 26 \\
1 yıldan fazla süre sonra & 8 & 16 \\
\hline 16-Hastalarınıza protez adezivi öneriyor musunuz? & & \\
\hline \hline Evet & 1 & 22 \\
Hayır & 39 & 78 \\
\hline 17-Hastalarınız protez adezivi kullanıma intiyacı & & \\
duyuyor mu? & & \\
\hline \hline Evet & 9 & 18 \\
Hayır & 41 & 82 \\
\hline 18-Total protez yapmayı seviyor musunuz? & & \\
\hline \hline Evet & 43 & 86 \\
Hayır & 7 & 14 \\
\hline
\end{tabular}

Ankete katılan diş hekimlerinin \%2'si herhangi bir preprotetik işlem yapmamaktadır. Bununla beraber $\% 96$ 'sı yüksek frenulum bağlantılarını kontrol etmekte, \%94'ü kemik ve yumuşak doku andırkatlarını, \%92'si labil kreti, \%86'sı malign ve benign yumuşak doku lezyonları bakımından oral mukozayı incelemektedir. \%80'i intermaksiller kret ilişkilerini, \%78'i fıbröz doku hiperplazilerini, eksoztozları ve torusları, \% 74'i ise yalnız kret boyu, genişliği ve şeklini incelemektedir. Ankete katılan diş hekimlerinin \%96'sı hastalarından panoromik radyografi almakta, \%4'ise hastalarından panoromik radyografi almadan tedaviye başlamaktadır.

Ankete katılan diş hekimlerinin \%90'ı hastalarına implant ile tedavi önermekle, \%10'u ise önermemektedir. Ankete katılan diş hekimlerinin \%12'si hastalarına diş üstü protezler önermekte, \%22'si ise önermemektedir.

Ankete katılan diş hekimlerinin \%96'sı preprotetik incelemeler sonrası gerektiğinde cerrahi konsül-

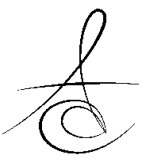


tasyon almakta, \%4'ü ise almamaktadır. Ankete katılan diş hekimlerinin \%92'si preprotetik işlemler için cerrahi uzmanına danışmaktadır, \%20'si ise preprotetik işlemleri kendisi yapmaktadır. Ankete katılan diş hekimlerinden gerekli durumlarda hiçbir preprotetik işlem yapmayan hekim bulunmamıştır.

Ankete katılan diş hekimlerinin \%44'ü gerektiği durumlarda teşhis ölçüsü almakta, \%44'ü teşhis ölçüsü almamakta ve \%10'u her durumda teşhis ölçüsü almaktadır. Ankete katılan diş hekimlerinin \%54'ü teşhis modeli alırken irreversibl hidrokolloid ölçü materyali kullanmaktadır, teşhis ölçüsü almak için termoplastik ölçü materyali, ölçü alçısı ve silikon esaslı ölçü materyali kullanan hekim yoktur.

Ankete katılan diş hekimlerinin \%90'ı bireysel kaşık kullanmakta, \%10'u ise bireysel kaşık kullanmamaktadır. Bireysel kaşık kullanan hekimlerin tümü bireysel kaşığı teknisyenine hazırlatmaktadır. Ankete katılan diş hekimlerinin \%54'ü bireysel kaşık materyali olarak akrilik rezin, \%48'i bazplak, \%38'i ise ışıkla sertleşen akrilik rezin kullanmaktadır. Ankete katılan diş hekimlerinin \%50'si ikinci ölçü alırken çinko oksit öjenol ölçü materyali, \%38'i irreversibl hidrokolloid ölçü materyali, \%10'u silikon esaslı ölçü materyali, \%2'si ölçü alçısı kullanmakta, \%4'ü ikinci ölçü almamaktadır.

Ankete katılan diş hekimlerinin \%58'i bireysel kaşıkların kenarlarını termoplastik ölçü materyaliyle şekillendirmekte, \%22'si ise bu işlem için silikon esaslı kenar şekillendirme materyali kullanmaktadır. Ankete katılan diş hekimlerinin \%20'si bireysel kaşıkların kenar- larına şekillendirme yapmamaktadır. Ankete katılan diş hekimlerinin \%56'sı bireysel ölçü kaşıklarını stoplu, \%16'sı mum stoplu ve \%14'ü ise stopsuz hazırlamak- tadır. Ankete katılan diş hekimlerinin \%62'si akilik rezinden, \%36'sı bazplaktan ve \%32'si ışıkla sertleşen akrilikten hazırlanmış kaide plakları kullanmaktadır. Ankete katılan diş hekimlerinin \%66'sı hamur yöntemiyle hazırlanmış akrilik kaide plağı kullanmaktadır. Serpme yöntemiyle hazırlanmış akrilik kaide plağı kullanan diş hekimi bulunmamıştır. Ankete katılan diş hekimlerinin \%66'sı kaide plağının retansiyonunda problem varsa, bunun tolere edilebileceğini, \%28'i ise kaide plağı retansiyonunun bitmiş bir protez kadar olması gerektiğini, \%2'si ise kaide plağının retansiyonunun çok önemli olmadığını belirtmiştir.

Ankete katılan diş hekimlerinin \%70'i mum duvarı bitmiş protezde dişlerin vestibül yüzlerinin bulunacağı konuma göre ayarlamakta,\%22'si alveoler kret şekline uygun hazırlamakta,\%8'i ise herhangi bir ayarlama yapmadan yalnızca mum ruloları yerleştirmektedir.

Ankete katılan diş hekimlerinin \%96'sı mum duvar şekillendirmesinde okluzal düzlemi, \%78'i pupiller düzlemi ve \%36'sı Camper düzlemini kontrol etmektedir. Ankete katılan diş hekimlerinin \%96'sı mandibulada mum duvarların alveol ket üzerinde bulunmasını, $\% 82$ 'si mum duvarların nötral zona yerleştirilmesini, $\% 62$ 'si mum duvar-komissura hizasını, \%48'i ise mum duvarın retromolar bölgenin 2/3'ünde bitirilmesini kontrol etmektedir, maksillada diş hekimlerinin \%78'i mum duvar alt dudak mesafesini kontrol etmektedir. Mum duvar şekillendirmesinde rehber faktörleri kullanmayan diş hekimi bulunmamıştır. Ankete katılan diş hekimlerinin \%90'ı dikey boyut belirleme amacıyla Niswonger yöntemini, \%72'si yutkunma yöntemini, \%68'i Silverman yöntemini kullanmakta, \%34'ü alveol kretlerinin paralelliğinden, \%18'i varsa eski protezin dikey boyutundan yararlanmaktadır. Dikey boyut belirleme amacıyla Boos yöntemini kullanan diş hekimi bulunmamıştır. Hiçbir diş hekimi dikey boyut amacıyla herhangi bir yöntem kullanmadan, direk mum duvarları ısıtıp dikey boyut almamıştır. Ankete katılan diş hekimlerinin \%88'i dikey boyutu tespit ederken burun ve çene ucunun birbirine yakınlığını, \%66'sı dudaklar temas halindeyken çeneler arası mesafeyi, \%52'si dudak kommisuralarını, \%50'si dudakların gerginliğini, $\% 50$ 'si nasolabial sulkusu, \%48'i mentolabial sulkusu, \%34'ü ise nasolabial açıyı kontrol etmektedir. Ankete katılan diş hekimleri arasında, bu noktaları kontrol etmeyen hekim bulunmamıştır.

Ankete katılan diş hekimlerinin \%54'ü Camper düzlemini kontrol ederken, \%34'ü ise kontrol etmemektedir. Ankete katılan diş hekimlerinin \%6'sı yüz arkı kaydı almaktadır. Yüz arkı kaydı almayan diş hekimlerinin \%60'ı teknisyende yüz arkı transferi kabul edecek artikülatör bulunmamasından, \%38'i klinikte yüz arkı bulunmamasından, \%28'i yüz arkı transferi kullanmadan da yeterli protezler yapılabildiğinden, \%26'sı zaman alıcı olmasından, \%24'ü zahmetli olmasından, \%16'sı yüz arkı kullanımının gerekliliğine inanmadığından ve \%6'sı da kullanım bilgisi eksikliğinden dolayı yüz arkı kullanmadıklarını beyan etmiştir. Ankete katılan diş hekimlerinin \%46'sı yüz arkı transferiyle yapılmış bir protezle, yüz arkı transferi yapılmamış bir protez arasında klinik başarı açısından hiçbir

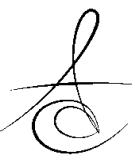


fark olmadığını düşünmektedir. Ayrıca ankete katılan diş hekimlerinin \%42'si oklüzal uyumlamalar sonrası giderilebilecek kadar bir fark olduğunu ve \%10'u da aralarında belirgin bir fark olduğunu düşünmektedir. Ankete katılan diş hekimlerinin \%66'sı çalıştıkları diş teknisyeninin yüz arkı transferi hakkında yeterli bilgi ve ekipmana sahip olmadığını, \%6'sı ise sahip olduğunu belirtmiştir.

Ankete katılan diş hekimlerinin \%96'sı dilin damağın en gerisine konulmasıyla mum duvarları sabitleyerek, \%92'si yutkunma yöntemini kullanarak, \%50'si çift el ile manipülasyon tekniği kullanarak, \%36'sı çene ucu rehberliği tekniği kullanarak sentrik ilişki tespiti yapmaktadır. Ankete katılan diş hekimlerinin hiçbiri gotik ark çizimi ve terminal menteşe ekseni kayıt yöntemini kullanmamaktadır. Ankete katılan diş hekimlerinin \%92'si diş seçiminde yapay dişin formunu seçerken hastanın cinsiyetini, \%92'si hastanın yaşını, \%80'i yüz şeklini, \%80 ise hastanın isteğini göz önünde bulundurmaktadır. Ankete katılan diş hekimlerinin hiçbiri diş formu seçimini hastaya sormadan yapmamaktadır ve teknisyene bırakmamaktadır.

Ankete katılan diş hekimlerinin \%96'sı yapay dişlerin rengini seçerken hastanın isteğine. \%86'sı hastanın yaşına dikkat etmektedir. Ankete katılan diş hekimlerinin hiçbiri diş rengi seçimini hastaya sormadan yapmamaktadır ve teknisyene bırakmamaktadır. Ankete katılan diş hekimlerinin \%14'ü total protezlerde porselen dişler, \%92'si ise akrilik dişleri tercih etmektedir.

Ankete katılan diş hekimlerimin \%90'ı anterior diş dizimin de simetriye, 88'i dudak desteğine, \%86'sı dişlerin şekil, renk ve yüz şekliyle ilişkisine, \%70'i dişlerin insizal kısımlarının alt dudak trajesiyle uyumlu olmasına, \%56'sı servikal bütünlüğe, \%42'si açık renkli diş seçimine, \%18'i porselen dişlerin akrilik dişlere tercih edilmesine, \%4'ü doğal, hafif çapraşık diş dizimine önem vermektedir. Ankete katılan diş hekimlerinin hiçbiri dişlerin insizal kenarlarını tek düzlemde dizmemekte ve diş dizimini teknisyene bırakma maktadır.

Ankete katılan diş hekimlerinin \%100'ü posterior diş dizimin de Spee eğrisi tesis edilmesine, \%66'sı dişlerin alveol kretinin üzerine dizilmesine, \%60'ı dişlerin akslarına. \%54'ü sağ sol arkın aynı düzlemde bulunmasına. \%52'si Wilson eğrisi tesis edilmesine, \%10'u ise maksiller dişlerin mandibular dişleri bir premolar kadar örtmesine dikkat etmektedir. Diş dizimini teknisyene bırakan hekim bulunmamıştır.
Ankete katılan diş hekimlerinin \%92'si dişli provada diş dizimi kurallarına, \%76'sı sentrik ilişkiyle sentrik oklüzyonun çakışmasına, \%62'si sağ sol arkların simetrisine, \%62'si dikey boyutun tekrar kontrol edilmesine, \%40' protruziv ve lateral balansta full balans sağlamaya, \%38'i üç nokta balansı sağlamaya dikkat etmektedir. Ankete katılan diş hekimlerinin $\% 86$ 'sı artikülasyon kanunlarını tam olarak bilirken, $\% 10$ 'u bilmemektedir. Ankete katılan diş hekimlerinin \%80'i artikülasyon kanunlarını yaptıkları protezlerde göz önüne alırken, \%18'i göz önüne almamaktadır. Ankete katılan diş hekimlerinin \%82'si artikülasyon kanunlarını bilmenin önemli olduğunu, \%16'sı ise önemli olmadığını düşünmektedir.

Ankete katılan diş hekimlerinin \%50'si bir total protezi 4-5 seansta, \%50'si ise 6-7 seansta bitirmektedir. Ankete katılan diş hekimleri arasında total protezi 2-3 seansta bitiren hekim bulunmamıştır.

Ankete katılan diş hekimlerinin \%32'si tam protezleri uyumlarken Herbst testlerinden faydalanırken, $\% 12$ 'si faydalanmamaktadır. Ankete katılan diş hekimlerinin \%58'i hastalarını 2-3 gün sonra ilk kontrole çağırmakta, \%28'i 4-5 gün sonra, \%8'i 1 hafta sonra, \%4'ü ise 1 gün sonra ilk kontrole çağırmaktadır. Ankete katılan diş hekimleri arasında hastasını 1 haftadan fazla süre sonra ilk kontrole çağıran hekim bulunmamıştır. Ankete katılan diş hekimlerinin \%86'sı mandibulada protez stabilizasyonunu çoğunlukla sağladığını, \%10'ü tüm hastalarında sağladığını, \%4'ü nadiren sağlayabildiğini belirtmiştir. Ankete katılan diş hekimleri arasında mandibulada protez stabilizasyonunu sağlayamayan hekim bulunmamıştır. Ankete katılan diş hekimlerinin \%54'ü maksillada protez stabilizasyonunu tüm hastalarında sağladığını ve \%46'sı çoğunlukla sağladığını belirtmiştir. Ankete katılan diş hekimleri arasında maksillada protez stabilizasyonunu nadiren sağlayabilen veya sağlayamayan hekim bulunmamıştır. Ankete katılan diş hekimlerinin \%52'si hastalarının yapılan protezlerden memnun olduğunu ve \%48'i çoğunlukla memnun olduklarını belirtmiştir. Ankete katılan diş hekimleri arasında hastaları kısmen memnun olan veya memnun olmayan hekim bulunmamıştır.

Ankete katılan diş hekimlerinin \%50'si kendi yaptığı protezlerden memnun ve \%50'si ise çoğunlukla memnundur. Ankete katılan diş hekimleri arasında yaptığı protezden kısmen memnun olan veya memnun olmayan diş hekimi bulunmamıştır. 
Ankete katılan diş hekimlerinin \%82'si protezin başarısının kullanılan materyal ve tekniklerle beraber hekimin tecrübesiyle bağlantılı olduğunu, \%10'u hekimin tecrübesinden çok, kullanılan materyal ve tekniklerle bağlantılı olduğunu, \%8'i ise kullanılan materyal ve tekniklerden çok, hekimin tecrübesiyle bağlantılı olduğunu belirtmiştir.

Ankete katılan diş hekimlerinin \%36'sı total protez uyguladıkları hastalarını 6 ayda bir, \%26'sı yılda bir, \%6'sı 3 ayda bir, \%32'si hiç kontrol etmemektedirler. \%54'ü yaptıkları protezlerden sonra besleme intiyacı duymamaktadır, \%26'sı 6 ay ile 1 yıl içinde, $\% 16$ 'sı 1 yıldan fazla süre sonra, \%2'si hastaya teslimden sonraki bir ay içinde ve \%2'si de teslimden hemen önce beslemeye ihtiyaç duymaktadır.

Ankete katılan diş hekimlerinin \%78'i protez tesliminden sonra hastalarına protez adezivi kullanmalarını önermemekte, \%22'si önermekte, \%82'sinin hastaları protez tesliminden sonra protez adezivi kullanma ihtiyacı duymamakta, \%18'i ise duymaktadır.

Ankete katılan diş hekimlerinin \%86'sı total protez yapmayı sevdiklerini, \%14'ü ise total protez yapmayı sevmediklerini belirtmişlerdir.

\section{TARTIŞMA}

Araştırmamızın sonuçlarına göre; serbest çalışan diş hekimleri, total protez yapımı esnasında, eğitimleri süresince aldıkları total protez eğitimiyle benzer şekilde aşamaları uygulamakta, benzer materyaller ve tekniklerle tedavilerini yapmaktadır. Singh ve arkadaşları $^{7} 2010$ yılında serbest çalışan diş hekimlerinin kullandıkları teknikleri incelemişlerdir. Elde edilen sonuçlar karşılaştırıldığında benzer sonuçlar elde edilmiştir. Çalışmamızda, tedavi öncesi teşhis ölçüsü alan diş hekimlerinin oranı \%54 iken Singh ve arkadaşlarının ${ }^{7}$ yaptığı araştırmada tedavi öncesi teşhis ölçüsü alan diş hekimlerinin oranı \%61.7 olarak bulunmuştur. Araştırmamızda, teşhis ölçüsü alımında irreversible hidrokolloid ölçü materyali kullanım oranı \%100, dikey boyut belirleme amaçlı kullanılan metotlardan Niswonger metodu kullanım oranı $\% 90$ iken, Singh ve arkadaşlar ${ }^{17}$ tespit ettiği oran sırası ile \%71 ve \%67.2'dir.

Hyde ve arkadaşlarının ${ }^{8} 1999$ yılında yaptıkları bir araştırmada diş hekimlerinin ikinci ölçü alımında tercih ettikleri materyaller sorgulanmış ve diş hekimlerinin \%94'ünün ikinci ölçü alımında irreversible hidrokolloid ölçü materyalini tercih ettiği görülmüştür. İkinci ölçü için irreversible hidrokolloid materyalini \%29 ile çinko oksit öjenol ve \%13 ile polivinil siloksan izlemiştir. Araştırmamızda diş hekimlerinin \%50'sinin ikinci ölçü alımında çinko oksit öjenol ölçü materyalini tercih ettiği görülmüştür. İkinci ölçü için çinko oksit öjenol ölçü materyalini \%38 ile irreversible hidrokolloid ve \%10 ile silikon esası ölçü materyalini izlemiştir.

Kakatkar ve arkadaşlarının ${ }^{9} 2013$ yılında yaptıkları bir araştırmada, birinci ölçü alımında diş hekimlerinin \%78'inin termoplastik ölçü materyali ve \%21'inin irreversible hidrokolloid ölçü materyalini kullandığı görülmüştür. Bireysel kaşık yapımında, diş hekimlerinin $\% 67$ 'si kimyasal olarak polimerize olan akriliği, \%33'ü bazplak kullandığı tespit edilmiştir. Bireysel kaşık kenarlarının şekillendirilmesinde diş hekimlerinin \%83'ü termoplastik ölçü materyali kullanırken, \%17'sinin silikon esaslı kenar şekillendirme materyali kullandığı görülmüştür. İkinci ölçüler için ise, diş hekimlerinin \%73'ünün çinko oksit öjenol, \%19'unun silikon esaslı ölçü materyali ve \%8'inin irreversible hidrokolloid ölçü materyali kullandığı görülmüştür. Çalışmamızda anket sorusuna cevap veren diş hekimlerinin \%100'ünün birinci ölçü alımında irreversible hidrokolloid ölçü materyali kullandığı görülmüştür. İkinci ölçü alımında diş hekimlerinin \%54' ünün ikinci ölçü alırken kimyasal olarak polimerize olan akrilik rezinle hazırlanmış kaşıklar kullandığı, \%48'nin baz plak ve \%38'inin ışıkla polimerize olan akrilik rezin kullandığı görülmüştür. Bireysel kaşıkların kenar şekillendirilmesinde hekimlerin \%58'inin termoplastik ölçü materyali, \% 22'sinin ise silikon esaslı kenar şekillendirme materyali kullandığı tespit edilmiştir. Araştırmaya katılan diş hekimlerinin \%50' sinin ikinci ölçü materyali olarak, çinko oksit öjenol, $\% 38$ 'inin irreversible hidrokolloid ve \%10'unun ise silikon esaslı ölçü materyalini tercih ettiği görülmüştür.

Drago'nun ${ }^{10} 2003$ yılında yaptığı çalışmada, bireysel kaşıklarının kenar şekillendirmeleri termoplastik ve silikon esaslı materyallerle yapılan iki hasta grubunu incelenmiş ve tedavi sonrası bir sene içerisinde kullanım şikâyeti açısından iki grup arasında anlamlı bir fark bulunamamıştır. Wang ve arkadaşları ${ }^{11}$ 2008 yılında yaptıkları bir araştırmada, araştırmaya katılan diş hekimlerinin \%97'sinin nadiren yüz arkı kullandığını ve \%92'sinin, tedavi ettikleri hastaların $\% 90$ 'ının total protezlerini kullanmaktan memnun olduklarını belirtmişlerdir. Ankete katılan diş hekimlerinin \%39'u yüz arkı kullanmamanın yapılan total protezin kalitesini düşüreceğini belirtmiştir. Araştırmamızda, ankete katılan diş hekimlerinin \%94'ünün yüz arkı kul-

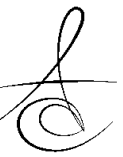


lanmadığı belirlenmiş ve araştırmaya katılan diş hekimlerinin \%52'si tedavi ettikleri hastaların total protezlerinden memnun olduğunu ve \%48'i ise tedavi ettikleri hastaların total protezlerinden çoğunlukla memnun olduğunu belirtmiştir. Ankete katılan diş hekimlerinin \%10'u yüz arkı ile yapılan ve yüz arkı kullanmadan yapılan protezler arasında belirgin bir fark olduğunu, \%46'sı hiçbir fark olmadığını ve \%42'si oklüzal uyumlamalar sonrası giderilebilecek kadar bir fark olduğunu belirtmiştir. Araştırmamıza katılan diş hekimlerinin \%82'si yapılan total protezlerin başarısının kullanılan materyal ve tekniklerle beraber, hekimin tecrübesiyle bağlantılı olduğunu belirtmiştir. Kimoto ve arkadaşlarının $^{12} 2013$ yılında yaptıkları bir araştırmaya göre, hekimin tecrübesinin total protez kullanan hastaların memnuniyetiyle doğru orantılı olduğu görülmüştür. Ancak, Akyıl ve arkadaşları ${ }^{13}$, hastaların memnuniyet düzeylerinin değerlendirilmesinde önemli veya orta derecede memnuniyetsiz olunan unsurun alt tam protezin çiğneme kabiliyeti olduğunu, bununla birlikte, bu hastaların en yüksek dental, durumluk ve sürekli anksiyete ortalamasına sahip olduğunu ortaya koymuşlardır.

\section{SONUÇ}

Çalışmamızda elde edilen veriler doğrultusunda, serbest çalışan diş hekimlerinin total protez yapım aşamasında ve sonrasında fakültede öğretilen yöntem ve materyallere yakın teknikler ve materyalleri kullandıkları tespit edilmiştir.

\section{KAYNAKLAR}

1. Çalıkkocaoğlu S. Dişsiz Hastaların Protetik Tedavisi Klasik Tam Protezler. 5. baskı. Quintessence Yayıncılık Ltd. Şti. İstanbul: 2010. p. 62-437.

2. Jamieson $\mathrm{CH}$. A modern concept of complete dentures. J Prosthet Dent 1956;6:582-92.

3. Kulak Özkan Y. Tam Protezler ve İmplant üstü Hareketli Protezler Problemler ve Çözüm Yolları. 1. Baskı. Vestiyer Yayın Grubu; İstanbul: 2012p. 176, 57-456.

4. Winkler S. Essentials of Complete Denture Prosthodontics. 2th ed. Mosby Year Book Inc. USA: 1988.p.44.

5. Clark DM, Oyen OJ. The use of specific dental school-taught restorative techniques by practicing clinicians. J Dent Educ 2001;65:760-5.

6. Shwarz WD, Barbys MJ. A survey of practise of partial denture prosthetics in the United Kingtom. J
Dent 1980;8:95-101.

7. Singh G. Kapoor V, Gambhir R, Bansal V. Application Of Prosthodontic Techniques By Private Practitioners In Norüern India- A Survey. Int J Epidem 2010;9:1-7.

8. Hyde TP, McCord JF. Survey of prosthodontic impression procedures for complete dentures in general dental practice in the United Kingdom. J Prosthet Dent 1999;81:295-9.

9. Kakatkar VR. Complete Denture Impression Techniques Practiced by Private Dental Practitioners: A Survey. J Indian Prosthodont Soc 2013;13:233-5.

10. Drago CJ. A Retrospective Comparison of Two Definitive Impression Techniques and Their Associated Postinsertion Adjustments in Complete Denture Prosthodontics. J Prostodont 2003;12:192-7.

11. Wang MQ, Xue F, Chen J, Fu K, Cao Y, Raustia A. Evaluation of the use of and attitudes towards a face-bow in complete denture fabrication: a pilot questionnaire investigation in Chinese prosthodontists. J Oral Rehabil 2008;35:677-81.

12. Kimoto S, Kimoto K, Kitamura A, Saita M, Iijima $M$, Kawai $Y$. Effect of dentist's clinical experience on treatment satisfaction of a complete denture. J Oral Rehabil 2013;40:940-7.

13. Akyıl MŞ, Duymuş ZY, Akova T, Uzun İH, Okanlı A. Farklı iki bölgede yaşayan hasta grubunda dental ve durumluk-sürekli anksiyete düzeyinin tam protez memnuniyetine etkisi. Atatürk Üniv Diş Hek Fak Derg 2007;17:1-10.

\section{Yazışma Adresi}

Dr. Ş. Begüm Türker

Marmara Üniversitesi Diş Hekimliği Fakültesi

34854 Başıüyük, Maltepe

İstanbul, Türkiye

e-mail: begumturker @ hotmail.com 